\title{
Reproductive health practices of rural mothers in Bangladesh: Community-based learning experiences for medical students
}

\author{
Md. Mahfuzar Rahman ${ }^{1}$, Md. Atiqur Rahman ${ }^{2}$, Tabassum Tahmin Sajani ${ }^{3}$ \\ ${ }^{1}$ Professor and Head; ${ }^{2,3}$ Assistant Professor; Department of Community Medicine, Anwer Khan Modern Medical College, Dhaka, \\ Bangladesh.
}

\begin{abstract}
Reproductive health is an emerging issue in Bangladesh as well as in the world. This was a survey conducted among rural women of the reproductive age group as a part of academic exposure of the medical students in community medicine during the Residential Field Site Training (RFST) program. The study aimed to determine antenatal and natal services, nature of complications during last delivery, and health problems related to the reproductive tract. The study also highlighted the views of the students in various aspects of the RFST program during development and implementation. A descriptive cross-sectional study was carried among 534 married women of reproductive age during December 2012 in different villages of Dhamrai Upazila, Dhaka. Medical students collected the data using a pre-tested questionnaire through face to face interview. The student's feedback was collected through another questionnaire using Likert 5-points scale. The study revealed that the mean age of respondents was $29 \pm 7.3$ years, $86 \%$ were housewives, $58 \%$ had $2-4$ children and mean age of the respondents at first issue was $19 \pm 3.5$ years. The study showed that $75.7 \%$ and $75.4 \%$ respondents received antenatal visits and TT immunization respectively. Among the respondents $48 \%$ had hospital delivery and $52 \%$ had home delivery, of which $30 \%$ were by skilled and $22 \%$ were by untrained birth attendants. The common reproductive health problems in relation to delivery were obstructed labor $(28 \%)$, PPH (22\%) and abortion $(21 \%$.) Other related reproductive health problems included: menstrual disturbance (52\%), leucorrhoea (41\%) and UTI (35\%). In this study, students expressed their satisfaction about the RFST program except duration of program. Medical students should provide opportunities to learn about reproductive health in a community-based setting which helped to increase their skills and confidence.
\end{abstract}

Keywords: Reproductive health, Rural mothers, RFST program, Students' experiences, Bangladesh.

\section{Introduction}

Reproductive health implies that people are able to have a responsible, satisfying and safe sexual life and that they have the capability to reproduce and the freedom to decide if, when and how often to do so. ${ }^{1}$ In the past few years, the issues of reproductive health have been increasingly perceived as social problem; they have emerged as a matter of increasing concern throughout the developed and developing countries. ${ }^{2}$ The reproductive health approach is concerned not only with pregnancy related health issue, but also with health and human right issues relevant to reproductive and sexuality that arise with health and human rights issues relevant to reproductive and sexuality that arise within and outside the child bearing age. ${ }^{2}$

Women reproductive health is relatively a new area of health intervention in Bangladesh and recently it emerges as an important issue. ${ }^{1}$ Many countries have become increasingly involved in monitoring reproductive rights and use the reporting procedures for international human rights instruments that their governments have ratified. ${ }^{2}$ In Bangladesh, the barriers towards establishment of women's sexual and reproductive health rights are in everlasting difficulty due to malnutrition, illiteracy, and

\section{Practice Points}

- The magnitude of women's reproductive health problems in Bangladesh is a serious matter of concern.

- The study shows that $75.6 \%$ respondents received antenatal visits, $79 \%$ respondents received TT immunization and $52 \%$ had home delivery of which $30 \%$ were by skilled and $22 \%$ were by untrained birth attendants.

- The common reproductive health problems in relation to delivery were obstructed labor (28\%), PPH (22\%) and abortion (21\%). Other related reproductive health problems included: menstrual disturbance leucorrhoea and UTI.

- Medical students expressed their satisfaction about the RFST program except duration of the program.

- Medical students should provide opportunities to learn about reproductive health in community -based settings which helped to increase their skills and confidence.

Correspondence: Prof. Md. Mahfuzar Rahman, Professor and Head Dept. of Community Medicine, Anwer Khan Modern Medical College, Dhaka, Bangladesh. E-mail: mahfuzarrahman26@yahoo.com. 
higher gender inequality. ${ }^{3}$ Study on reproductive health rights reveals a wide range of socio-economic and demographic factors which affect women's empowerment, education and reproductive health rights. ${ }^{4}$

The maternal mortality ratio (MGD 5) in Bangladesh is 240 , which is one of the highest in the region. ${ }^{5}$ Despite efforts to expand emergency obstetric care by the government and non-governmental organizations, hospital deliveries remain at a low level. There are also concerns about the availability and quality of skilled birth attendance. ${ }^{6}$ The low status of women, poor quality and low uptake of services all add to this problem. ${ }^{1}$

According to the 2011 BDHS (Bangladesh Demographic and Health Survey), 26\% of women who had a child in the last three years received the recommended four or more antenatal care (ANC) visits and $29 \%$ of recent births took place in a health care facility. ${ }^{1}$ Motivating more women to utilize public and private health care early in pregnancy is critical to improving maternal and child health. ${ }^{7}$ It was found that women who receive ANC are much more likely to deliver in a facility and to receive postnatal care than women who do not see skilled providers during pregnancy.

The Ministry of Health and Family Welfare, Bangladesh adopted the Health and Population Sector Strategy (HPSS) in 1998 to provide a package of essential health care services for the people of Bangladesh and to slow down population growth. ${ }^{8}$ The main sectorial objectives of the HPSS are: maintenance of the momentum of efforts in Bangladesh to lower fertility and reduce mortality, reduction of maternal mortality and morbidity and reduction in the burden of communicable diseases. ${ }^{8}$

The present study was among rural women of reproductive age group as a part of academic exposure of the medical students in community medicine during Residential Field Site Training (RFST) program. The study aimed to determine antenatal and natal services, nature of complications during last delivery, and health problems related to reproductive tract. The study also highlighted the views of the students in various aspects of the RFST program during development and implementation

\section{Materials and Methods}

This was a descriptive cross-sectional study carried among 534 married women of reproductive age during December 2012 in different villages of Dhamrai Upazila, Dhaka. The selection of sample was purposive in nature. The data were collected by a pre-tested structured questionnaire through face to face interview. Thirty five $4^{\text {th }}$ year MBBS students of Anwer Khan Modern Medical College (Dhanmondi, Dhaka) as a part of their RFST training interviewed the rural women. The women filled up a consent form and signed by the respondent as a part of ethical consideration. The student's feedback was collected through Likert 5 points scale. The feedback were mostly on various aspects of the program starting from survey protocol development, their involvement in implementation as well as acquisition of certain general competencies, and over all opportunities in practicing multi-dimensional skills in particular.

\section{Results}

Reproductive health practices among rural women The detailed socio-economic characteristics of the respondents are shown in Table 1. The mean age of the women was 29 years and most of them were housewives $(86 \%)$. Table 2 shows that about $75.7 \%$ respondents received antenatal visits and $75.4 \%$ respondent received TT immunization

The study also found that $48 \%$ respondents had their last delivery conducted by qualified doctors and about $30 \%$ and $22 \%$ had their last delivery conducted by skilled birth attendants and untrained birth attendants respectively.The common reproductive health problems in relation to delivery were obstructed labor $(28 \%)$, post partum hemorrhage $(22 \%)$ and abortion $(21 \%)$. Other related health problems included: menstrual disturbance $(52 \%)$, leucorrhoea (41\%) and UTI (35\%).

\section{Students views on RFST program}

Table 3 shows the detailed view of the students who attended the RFST program and interviewed the women. All of the students agreed that they were well aware about the objectives of the RFST program, involved in group activities, and got the opportunity in practicing interview skills. However, approximately

Table 1: Socio-demographic variables of the respondents

\begin{tabular}{|l|c|}
\hline Variables & $\begin{array}{c}\text { Findings } \\
(\mathbf{n}=\mathbf{5 3 4})\end{array}$ \\
\hline $\begin{array}{l}\text { Age (in years) } \\
\text { Mean age }( \pm \mathrm{SD})=\end{array}$ & $29 \pm 7.33$ \\
\hline $\begin{array}{l}\text { Religion } \\
\text { Muslims }\end{array}$ & $91 \%$ \\
\hline $\begin{array}{l}\text { Education } \\
\text { Literate }\end{array}$ & $85 \%$ \\
\hline $\begin{array}{l}\text { Occupation } \\
\text { Housewife }\end{array}$ & $86 \%$ \\
\hline $\begin{array}{l}\text { Monthly income (BDTK) } \\
\text { >9000 }\end{array}$ & $48 \%$ \\
\hline $\begin{array}{l}\text { Marital status } \\
\text { Married }\end{array}$ & $99 \%$ \\
\hline $\begin{array}{l}\text { Number of children } \\
\text { 1-2 Child } \\
\geq 4 \text {-Child }\end{array}$ & $88 \%$ \\
\hline $\begin{array}{l}\text { Age (years) at first issue } \\
\text { Mean age ( } \pm \text { SD) }\end{array}$ & $6 \%$ \\
\hline
\end{tabular}

Table 2: Antenatal visits and care provided to mothers

\begin{tabular}{|l|c|c|c|}
\hline Attributes & Yes & No & Total \\
\hline $\begin{array}{l}\text { Antenatal } \\
\text { visits }\end{array}$ & $404(75.7 \%)$ & $130(24.4 \%)$ & 534 \\
\hline $\begin{array}{l}\text { TT } \\
\text { immunization }\end{array}$ & $403(75.4 \%)$ & $131(24.5 \%)$ & 534 \\
\hline
\end{tabular}


Table 3: Medical student views on RFST program $(n=35)$

\begin{tabular}{|l|c|c|c|c|c|}
\hline \multicolumn{1}{|c|}{ Statements } & SA & A & UD & D & SD \\
\hline $\begin{array}{l}\text { Well aware about the objectives of RFST pro- } \\
\text { gram in conducting a survey }\end{array}$ & $30(85.7 \%)$ & $5(14.3 \%)$ & - & - & - \\
\hline Satisfied with the duration of RFST program & $5(14.3 \%)$ & $4(11.4 \%)$ & $3(8.6 \%)$ & $7(20 \%)$ & $16(45.7 \%)$ \\
\hline $\begin{array}{l}\text { Actively participated in the program to work in } \\
\text { community setting }\end{array}$ & $29(82.9 \%)$ & $3(8.6 \%)$ & $2(5.7 \%)$ & - & - \\
\hline $\begin{array}{l}\text { Opportunity to explore health problems in the } \\
\text { community }\end{array}$ & $24(68.6 \%)$ & $8(22.9 \%)$ & $2(5.7 \%)$ & $1(2.8 \%)$ & - \\
\hline $\begin{array}{l}\text { Involved in group activities during development } \\
\text { of survey protocol }\end{array}$ & $28(80 \%)$ & $7(20 \%)$ & - & - & - \\
\hline $\begin{array}{l}\text { Opportunity in practicing interview skills during } \\
\text { survey }\end{array}$ & $26(74.3 \%)$ & $9(25.7 \%)$ & - & - & - \\
\hline $\begin{array}{l}\text { Exposed to health care delivery system at the } \\
\text { rural setting }\end{array}$ & $21(60 \%)$ & $9(25.7 \%)$ & $2(5.7 \%)$ & - & $3(8.6 \%)$ \\
\hline $\begin{array}{l}\text { Involved in handling data to prepare a report for } \\
\text { dissemination }\end{array}$ & $17(48.6 \%)$ & $16(45.7 \%)$ & - & - & $2(5.7 \%)$ \\
\hline $\begin{array}{l}\text { Good practice of time management during RFST } \\
\text { program }\end{array}$ & $24(68.6 \%)$ & $10(28.6 \%)$ & $1(2.8 \%)$ & - & - \\
\hline $\begin{array}{l}\text { Opportunity of developing stress bearing capa- } \\
\text { bilities to work in out campus settings }\end{array}$ & $20(57.2 \%)$ & $12(34.4 \%)$ & $1(2.8 \%)$ & $1(2.8 \%)$ & $1(2.8 \%)$ \\
\hline $\begin{array}{l}\text { Opportunities for practicing multi-dimensional } \\
\text { skills }\end{array}$ & $14(40 \%)$ & $18(51.5 \%)$ & $2(5.7 \%)$ & - & $1(2.8 \%)$ \\
\hline $\begin{array}{l}\text { Opportunities of dealing health problems in a } \\
\text { holistic way }\end{array}$ & $12(34.4 \%)$ & $17(48.6 \%)$ & $4(11.4 \%)$ & $1(2.8 \%)$ & $1(2.8 \%)$ \\
\hline
\end{tabular}

Keys: SA: strongly agree, A: agree, UD: undecided, D: disagree, SD: strongly disagree

$66 \%$ of the students showed their dissatisfaction with duration of the program. More than $80 \%$ of the students actively participated in program, explored the community health problems, exposed to health care delivery system at the rural setting, involved in data analysis and report writing, provided opportunities of practicing multi-dimensional skills in dealing health problems in a holistic way.

\section{Discussion}

The magnitude of women's reproductive health problems in Bangladesh is a serious matter of concern. ${ }^{1}$ Among the reproductive health indicators, ANC and safe delivery have important implications as these are directly related with maternal morbidity and mortality. ${ }^{2}$ The study found that three-quarters of the rural mothers received antenatal visits and TT immunization and 52\% experienced home delivery of which $30 \%$ by skilled and $22 \%$ by untrained birth attendants. A recent study conducted in rural Bangladesh by Shahjahan et al. ${ }^{9}$ found that $62.5 \%$ of the mothers received ANC services from health centers and $55 \%$ of the mothers had at least one or two visits, and $45 \%$ had recommended four and above ANC visits. The BDHS $2011^{1}$ showed that 55\% of women with a birth in the three years preceding the survey received ANC at least once and more than half $(55 \%)$ of the women received care from a medicallytrained providers.

The present study also found that $85 \%$ of the mothers were literate and almost half of them had high family income which may be cause of higher ANC and visits. Studies from Bangladesh ${ }^{9}$ and Indonesia $^{10}$ which showed that literacy of mothers had a significant association with the use of ANC services and care. High family income of mothers had the highest percentage use of ANC services as reported by studies from Bangladesh, ${ }^{11}$ Tamil Nadu (India) ${ }^{12}$ and Indonesia. ${ }^{10}$

In Bangladesh, about 12,000 women in die due to pregnancy-related complications. ${ }^{13}$ These complications can be managed and treated if timely and appropriate care is sought from facilities with necessary skilled care providers. ${ }^{13}$ It is important to note that Bangladesh has made a significant improvement towards achieving the Millennium Development Goal (MDG) target the 5 of $75 \%$ reduction in the MMR between 1990 and $2015 .{ }^{14} \mathrm{~A}$ recent study ${ }^{15}$ published in the Lancet reported that MMR in Bangladesh fell from 322 deaths per 100,000 live births in 1998-2001 to 194 deaths per 100,000 live births in 2007-10, an annual rate of decrease of $5 \cdot 6 \%$. The study highlighted that key contribution to this decrease was a drop in mortality risk mainly due to improved access to and use of health facilities and recommended to provide provisions for high quality facilities for maternal complications and safe delivery services in Bangladesh and elsewhere.

Residential field site training (RFST) is an approach to community based education in undergraduate medical curriculum in Bangladesh. ${ }^{16-18}$ Hospital-based education is no longer the only place to train doctors for the $21 \mathrm{st}$ century as it fails to develop generic skills of doctors. ${ }^{19}$ More exposure to community and its health problems is needed for students to produce competent doctors for the country. ${ }^{16-18}$ In this study, students expressed their satisfaction about the RFST program except duration of the program. Administrators and policy makers should review the program based on the student feedback. 


\section{Conclusion}

Reproductive health is an emerging issue in Bangladesh as well as in the world. The study concludes that acceptance of antenatal check up during last pregnancy have the greatest potentiality to enhance the women reproductive health behavior. Medical students had the opportunities to learn about reproductive health in a community-based setting which helped to increase their skills and confidence. Students found the program effective and hence duration of the program should be increased to provide adequate exposure to community health problems.

\section{References}

1. National Institute of Population Research and Training (NIPORT), Mitra and Associates, and ICF International. Bangladesh Demographic and Health Survey 2011. Dhaka, Bangladesh and Calverton, Maryland, USA: Mitra and Associates, and ICF International, 2013.

2. World Health Organization (WHO). Antenatal care in developing countries: promises, achievements and missed opportunities: an analysis of trends, levels and differentials, 1990-2001. Geneva: WHO, 2003.

3. Kane TT, Barkat-e-Khuda, Phillips JF. Reproductive Health in Rural Bangladesh: Policy and Programmatic. ICDDRB Monograph No 7. Vol 1. Dhaka: ICDDRB, 1997.

4. Rashid KM, Rahman M, Hyder H. Textbook of Community Medicine and Public Health. MCH and Reproductive Health. 4th edition. Dhaka: RHM Publishers, 2009.

5. Majumder MAA. Health care at a crossroads in Bangladesh. New York Sci J 2014;7(10):63-7.

6. Planning Commission, Government of the People's public of Bangladesh. The Millennium Development Goals. Bangladesh Progress Report 2009. Dhaka: General Economics Division, 2009.

7. Demographic and Health Survey. Marked improvements in maternal and child health in Bangladesh (Press release). http:// dhsprogram.com/Who-We-Are/News-Room/ Marked-improvements-in-maternal-and-childhealth-in-Bangladesh.cfm (accessed June 2014)

8. National Institute of Population Research and Training (NIPORT). Bangladesh Maternal Health Services and Maternal Mortality Survey. Dhaka: NIPORT, 2002.
9. Shahjahan M, Chowdhury HA, Akter J, Afroz A, Hafez MA. Factors associated with use of antenatal care services in a rural area of Bangladesh. South East Asia J Public Health 2012;2 (2):61-6.

10. Erlindawati, Chompikul J, Isaranurug S. Factors related to the utilization of antenatal care services among pregnant women at health centers in Aceh Besar district, Nanggroe Aceh Darussalam province, Indonesia. J Public Health Dev 2008; 6:99-108.

11. Rahman M, Islam R, Rahman M. Antenatal care seeking behaviour among slum mothers. A Study of Rajshahi City Corporation, Bangladesh. $S Q U$ Med $J$ 2010; 10:50-6.

12. Kavitha $\mathrm{N}$ and Audinarayana N: Utilisation and Determinants of Selected MCH Care Services in Rural Areas of Tamil Nadu. Health Popul - Perspect Issues 1997;20:112-25.

13. Anwar I, Kalim N, Koblinsky M. Quality of obstet-ric care in public-sector facilities and constraints to implementing emergency obstetric care services: evidence from high- and lowperforming districts of Bangladesh. $J$ Health Popul Nutr 2009;27:139-55.

14. WHO, UNICEF, UNFPA and World Bank. Trends in Maternal Mortality. 1990 to 2008. Estimated Developed by WHO, UNICEF, UNFPA, and the World Bank. Geneva: World Health Organization, 2010.

15. El Arifeen S, Hill K, Ahsan KZ, Jamil K, Nahar Q, Streatfield PK. Maternal mortality in Bangladesh: a Countdown to 2015 country case study. Lancet 2014;384(9951):1366-74.

16. FIMC Project. Residential Field Site Training Program. Dhaka: FIMC Project; 1997.

17. Majumder MAA. A review of the undergraduate medical curriculum in Bangladesh. Bangladesh Med J 2002;31:47-9.

18. Majumder MAA. Medical Education in Bangladesh: Past Successes, Future Challenges. Bangladesh Med J 2003;32:37-9.

19. Salam A, Yusuf R. Residential Field Site Training: Bangladesh approach to Communitybased education to develop generic skills in Tomorrows' Doctors. Middle East J Nurs 2009;3 (5):22-6. 